\title{
Correlation Between HbA1c and Albuminuria in Type 2 Diabetes Mellitus
}

\author{
Jesika Merlin, ${ }^{1}$ Pusparini ${ }^{2}$ \\ ${ }^{1}$ Medical Study Program, Faculty of Medicine, Trisakti University, Jakarta, Indonesia \\ ${ }^{2}$ Department of Clinical Pathology, Faculty of Medicine, Trisakti University, Jakarta, Indonesia
}

\begin{abstract}
In patients with type 2 diabetes mellitus (Type 2 DM), glycemic control plays an essential role in reducing macroand microvascular complications. The earliest marker for diabetic nephropathy is the presence of albuminuria. Meanwhile, HbA1c has been recognized as a marker of glycemic control in the blood. This study aimed to identify the correlation between HbA1c and albuminuria in type 2 DM. This was a cross-sectional study involving 100 patients with type 2 DM aged 40-70 years visiting Dr. Soetomo Hospital, Surabaya, Indonesia. Secondary data from medical records of type 2 DM patients undergoing HbA1c and albuminuria examinations from January to December 2015 were used. The mean age of subjects was $55.4 \pm 8.7$ years, with the majority (55\%) being of female gender. The mean HbA1c concentration was $9.8 \pm 2.4 \%$. Most subjects ( $83 \%$ ) had an HbA1c level of $\geq 7 \%$. Albuminuria was found in the majority of the subjects (78\%), where $33 \%$ of them had positive 1 albuminuria. The Spearman correlation test showed a positive strong significant correlation between HbA1c and albuminuria, with $r=0.865$ and $p<0.001$. Thus, it can be concluded that there is a significant correlation between HbA1c and albuminuria in type $2 \mathrm{DM}$.
\end{abstract}

Key words: Albuminuria, diabetic nephropathy, HbA1c, type 2 diabetes mellitus

\section{Korelasi HbA1c dan Albuminuria pada Diabetes Melitus Tipe 2}

\begin{abstract}
Abstrak
Pada penderita diabetes melitus tipe 2 (DM tipe 2), kontrol glikemik memegang peranan penting untuk menurunkan komplikasi makrovaskular dan mikrovaskular. Petanda awal terjadi nefropati diabetik adalah albuminuria. HBA1c merupakan petanda untuk mengetahui kontrol glikemik didalam darah. Tujuan penelitian ini untuk mengetahui korelasi antara HbA1c dengan albuminuria pada DM tipe 2. Penelitian ini menggunakan desain potong lintang, mengikutsertakan 100 penderita DM tipe 2 berusia 40-70 tahun di Rumah Sakit Dr. Soetomo Surabaya. Data yang digunakan adalah data sekunder dari rekam medis penderita DM tipe 2 yang melakukan pemeriksaan HbA1c dan albuminuria pada bulan Januari-Desember 2015. Rerata usia subjek adalah 55,47 $\pm 8,7$ tahun dengan subjek terbanyak berjenis kelamin perempuan (55\%). Rerata kadar HbA1c berkisar 9,8 $\pm 2,4 \%$. Sebagian besar subjek mempunyai kadar HbA1c $\geq 7 \%$ yaitu $83 \%$. Albuminuria dijumpai pada sebagian besar subjek, yaitu 78\% dan sebagian besar subjek mempunyai albuminuria positif 1, yaitu $33 \%$. Hasil uji korelasi Spearman menunjukkan terdapat korelasi positif kuat yang bermakna antara HbA1c dengan albuminuria dengan nilai $r=0,865$ dan $p<0,001$. Simpulan, terdapat korelasi yang bermakna antara HbA1c dan albuminuria pada DM tipe 2 .
\end{abstract}

Kata kunci : Albuminuria, diabetes melitus tipe 2, HbA1c, nefropati diabetik

Corresponding Author: Pusparini, Department of Clinical Pathology, Faculty of Medicine, Trisakti University, Jakarta, Jalan Kyai Tapa, Grogol, Jakarta Barat. Indonesia, Email: pusparini@trisakti.ac.id 


\section{Introduction}

Diabetes Mellitus (DM) is a chronic disease caused by the inability of the body to produce the insulin hormone or ineffective utilization of the produced insulin, which is marked by a high blood glucose concentration. The prevalence of DM is increasing rapidly, and it is estimated that, currently, $8.3 \%$ of adults worldwide are suffered from DM. The 2014 WHO Global Status Report on non-communicable disease (NCD) showed that $68 \%$ of worldwide mortality for all ages is related to NCDs. ${ }^{1}$ DM ranks sixth as the cause of death, with around 1.3 million persons dying from $\mathrm{DM}$, and $4 \%$ of these deaths occur before 70 years of age. By the year 2030, it is estimated that DM occupies the seventh rank as the cause of global mortality. In Indonesia, it is estimated that by 2030 , there will be 21.3 million patients with DM. ${ }^{2,3}$

The high prevalence of DM in Indonesia and its complications, such as retinopathy, nephropathy, diabetic gangrene, heart disease, and stroke, constitutes a significant threat to health development. The relationship between DM and end-stage kidney disease has been known to be the main result of diabetic nephropathy. ${ }^{4}$ Aggressive glycemic control plays an essential role in patients with type $2 \mathrm{DM}$, since it may prevent micro- and macrovascular complications of DM. There is evidence that longterm hyperglycemia may lead to the occurrence of microvascular complications, both in patients with type $1 \mathrm{DM}$ and type $2 \mathrm{DM}^{4}{ }^{4}$

Glycemic variability is a term used to describe disturbed glycemic control. Hemoglobin A1c (HbA1c) reflects long-term glycemic control and may be used for the diagnosis of DM. ${ }^{5}$ In addition to diagnosis, the HbA1c level may be used to predict the microvascular complications of DM, one of them being diabetic nephropathy. Diabetic nephropathy is marked by excessive excretion of albumin followed by a decrease in renal function. ${ }^{6}$

Albuminuria is the characteristic feature of diabetic nephropathy. Microalbuminuria is the principal early predictor of the development of glomerular diabetic nephropathy, and may be viewed as a measure of the severity of diabetic nephropathy and its development. ${ }^{6}$ Data from the United States showed that the percentage of adults with DM who are capable of achieving the target of glycemic control $\left(\mathrm{HbA}_{1 \mathrm{c}}\right)$ of $<7 \%$ tends to decrease from $52.2 \%$ in 2011 to $50.9 \%$ in $2014 .{ }^{7}$ To date there is still a difference in opinions concerning the relationship between long-term glycemic control $\left(\mathrm{HbA}_{1 \mathrm{c}}\right)$ and the occurrence of diabetic nephropathy. The study of Showail et al. ${ }^{4}$ stated that there is a significant relationship between uncontrolled glycemia and the occurrence of albuminuria. On the other hand, the study of Tarigan et al. ${ }^{8}$ declared no critical relationship between $\mathrm{HbA}_{1 \mathrm{c}}$ concentration and the occurrence of diabetic nephropathy in patients with type $2 \mathrm{DM}^{4,8}$ The present study aimed to determine the correlation between $\mathrm{HbA} 1 \mathrm{c}$ concentration and albuminuria in patients with type $2 \mathrm{DM}$.

\section{Methods}

This was a cross-sectional study conducted on 100 subjects based on secondary data from medical records in Dr. Soetomo Hospital, Surabaya. The inclusion criteria in the present study were patients with type 2 DM, aged 4070 years, and having $\mathrm{HbA1c}$ and albuminuria data in the medical records. The HbA1c determination was based on the turbidimetric inhibition immunoassay for hemolyzed whole blood at Cobas C311, whereas the albuminuria determination was based on dipstick urinalysis using Urisys 2400. Medical record data were collected from patients who underwent HbA1c and albuminuria examinations from January to December 2015. The exclusion criteria were incomplete medical records and pregnancy in the case of female patients. Glycemic control was considered to be good if $\mathrm{HbA} 1 \mathrm{c}<7 \%{ }^{7}$ This study obtained ethical clearance from the Ethics Commission of the Faculty of Medicine, Trisakti University, under Ethical Clearance no. 116/KER-FK/X/2015. Data were presented as percentage, mean, and standard deviation. In order to determine the relationship between HbA1c and albuminuria in type 2 DM, the Spearman correlation test was used at a level of significance of $\mathrm{p}<0.05$. Chi-Square analysis was used to analyze the value of the differences between two categorical parameters.

\section{Results}

The female and male ratio was 55:45 while the average age was $55.47 \pm 8.7$ years, of which $70 \%$ were $\leq 60$ years and $30 \%$ were over 60 years. The HbA1c concentration was $9.8 \pm 2.4 \%$; and the frequency of negative, $+1,+2$, and +3 albuminuria was $22 \%, 33 \%, 26 \%$, and $19 \%$ respectively (Table1). 
Table 1 Subject Characteristics

\begin{tabular}{cc}
\hline Characteristic & $\mathbf{n}(\%) / \mathbf{X} \pm \mathbf{S D}$ \\
\hline Gender & \\
Male & $45(45)$ \\
Female & $55(55)$ \\
Age (years) & $55.47 \pm 8.7$ \\
$\leq 60$ & $70(70)$ \\
$>60$ & $30(30)$ \\
HbA $_{1 \mathrm{C}}(\%)$ & $9.8 \pm 2.4$ \\
$<7$ & $17(17)$ \\
$\geq 7$ & $83(83)$ \\
Albuminuria & \\
Negative & $22(22)$ \\
+1 & $33(33)$ \\
+2 & $26(26)$ \\
+3 & $19(19)$ \\
\hline
\end{tabular}

There was no significant difference in glycemic controlled (HbA1c) between different genders $(p=0.209)$ and between the elderly

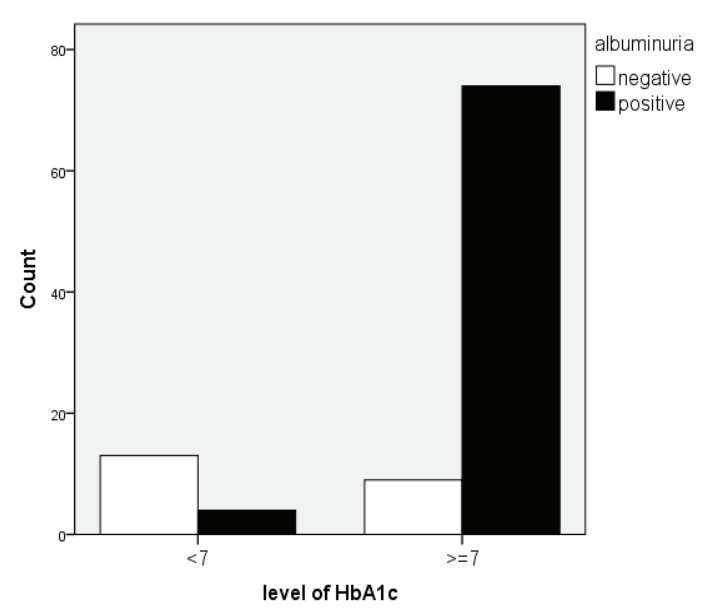

Figure 1 HbA1c Level and Albuminuria Degree

( $>60$ years) and younger ( $\leq 60$ years) groups ( $\mathrm{p}=0.523)$ (Table 2).

There was higher positive albuminuria cases in uncontrolled HbA1c level group with $\mathrm{p}<0.001$ (Table 4 and Figure 1).

Table 2 Relationship between HbA1c, Gender, andAge

\begin{tabular}{lcccc}
\hline \multirow{2}{*}{ Variable } & $\mathbf{n}$ & \multicolumn{2}{c}{ HbA1c (\%) } & \multirow{2}{*}{ p-value } \\
\cline { 3 - 4 } & & $\begin{array}{c}\text { Controlled } \\
(<7)\end{array}$ & $\begin{array}{c}\text { Uncontrolled } \\
(\geq 7)\end{array}$ & \\
\hline Gender & & & & \\
$\quad$ Male & 45 & 10 & 35 & 0.209 \\
$\quad$ Female & 55 & 7 & 48 & \\
Age (years) & & & & \\
$\quad \leq 60$ & 70 & 13 & 57 & 0.523 \\
$>60$ & 30 & 4 & 26 & \\
\hline
\end{tabular}

Chi-Square test; $\mathrm{p}<0.05=$ significant difference

Table 3 Relationship between Albuminuria, Gender, and Age

\begin{tabular}{lcccccc}
\hline \multirow{2}{*}{ Variable } & $\mathbf{n}$ & \multicolumn{5}{c}{ Albuminuria } \\
\cline { 3 - 7 } & & Negative & $\mathbf{+ 1}$ & $\mathbf{+ 2}$ & $\mathbf{+ 3}$ & $\mathbf{p}$-value \\
\hline Gender & 45 & 12 & 18 & 10 & 5 & 0.161 \\
$\quad$ Male & 55 & 10 & 15 & 16 & 14 & \\
$\quad$ Female & & & & & & \\
Age (years) & 70 & 16 & 26 & 14 & 14 & 0.363 \\
$\quad \leq 60$ & 30 & 6 & 7 & 12 & 5 & \\
$>60$ & & & &
\end{tabular}

Chi Square test; $\mathrm{p}<0.05=$ significant difference 
J Merlin and Pusparini: Correlation Between HbA1c and Albuminuria in Type 2 Diabetes Mellitus

Table 4 Relationship between Albuminuria and HbA1c

\begin{tabular}{lcccc}
\multicolumn{1}{r}{ HbA1c } & $\mathbf{n}$ & \multicolumn{3}{c}{ Albuminuria } \\
\cline { 3 - 5 } & & Negative & Positive & p-value \\
\hline$<7 \%$ (controlled) & 17 & 13 & 4 & 0,001 \\
$\geq 7 \%$ (uncontrolled) & 83 & 9 & 74 & \\
\hline
\end{tabular}

Chi Square test; $\mathrm{p}<0.05$ = significant difference

\section{Discussion}

$\mathrm{HbA1c}$ is a measure of glycated hemoglobin that estimates the mean blood glucose concentration over the erythrocyte life span of 120 days. HbA1c is most frequently used to evaluate long-term glycemic control in patients with DM. ${ }^{9}$

The study's results showed that the subjects had a signifying poor glycemic control (Table 1). As recommended by the American Diabetes Association (ADA), HbA1c is said to be controlled if it is $<7 \%$. When the level is $>7 \%$, the risk of both micro- and macrovascular complications increases. ${ }^{9}$ The study of Muraliswaran et al. ${ }^{10}$ on subjects aged between 30 to 70 yeas with a mean age of $53.98 \pm 12.74$ years revealed a mean HbA1c of $8.48 \pm 2.22 \%$. Several factors may influence HbA1c concentration, including age. It is evident that the higher the age of the subjects is, the higher the HbA1c concentration.7,11

In the present study, it was discovered that the subjects had the following degrees of albuminuria: negative, positive 1 , positive 2 , and positive 3 , with the highest percentage being positive 1 at $33 \%$. The study conducted by Muraliswaran et al. ${ }^{10}$ found a mean

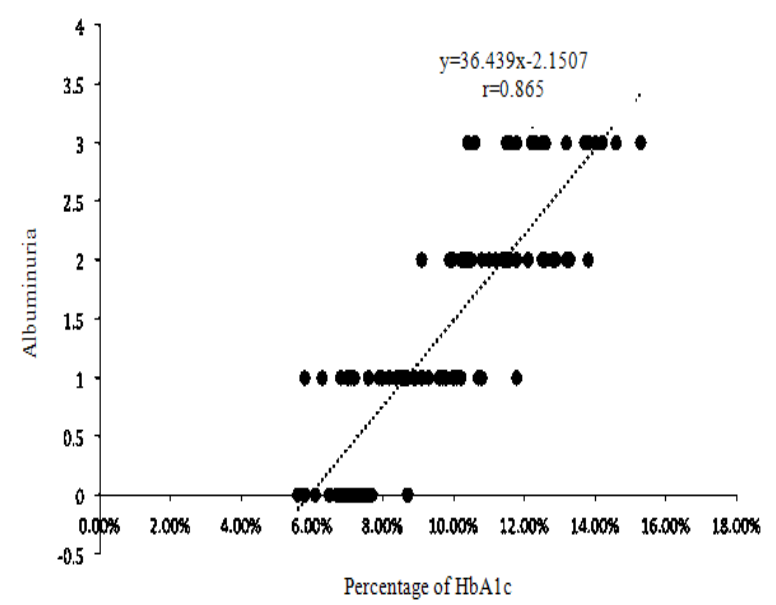

Figure 2 Correlation between $\mathrm{HbA1}_{\mathrm{c}}$ and Albuminuria in Type 2 DM microalbuminuria concentration of $26.25 \pm 13.11$. A survey performed in a community of white adults aged 20-65 years showed a prevalence of microalbuminuria of $6.3 \%{ }^{12}$ In persons aged 60-74 years, the prevalence increased from 13 to $20 \%$, so that the prevalence of albuminuria is said to increase with advancing age. ${ }^{13}$

The albuminuria values differ between individuals because, in addition to being the result of renal disease, it may also be caused by vigorous physical activities, dehydration, stress, fever, admixture of vaginal mucus, urinary tract infection, orthostatic proteinuria, pregnancy, thermal damage, and various inflammatory processes. ${ }^{14}$ Patients with DM have a prospect of renal damage that is measurable by increased urinary excretion of albumin. Albuminuria is known as a marker of early onset of renal damage and a risk factor for the development of a chronic renal disease, which finally leads to the end-stage renal disease (ESRD). ${ }^{15}$ An albumin secretion of 30-300 mg/day is termed microalbuminuria, with $<20 \mathrm{mg} /$ day considered normal. ${ }^{16}$ Persistent microalbuminuria is considered an early indicator of diabetic nephropathy. Patients with type $2 \mathrm{DM}$ and microalbuminuria will face increased long-term mortality and increased risk of macroalbuminuria. To date, the screening method of choice for microalbuminuria is the measurement of the albumin-creatinine ratio in random urine specimens thus avoiding the confounding effect of the variability of urinary volume, urinary albumin concentration, and/ or the need for collecting 24-hour urine. With the above-mentioned method, an albumin/ creatinine ratio of $30-300 \mathrm{mg} / \mathrm{g}$ is equivalent to albumin excretion of $30-300 \mathrm{mg} /$ day, indicating microalbuminuria. If the excretion of albumin/creatinine ratio exceeds 300 $\mathrm{mg} / \mathrm{g}$, macroalbuminuria can be diagnosed. ${ }^{17}$ Early detection of albuminuria and risk factor assessment may prevent the development of diabetic nephropathy. ${ }^{18}$

In Table 2, it can be seen that the glycemic control (HbA1c) is not associated with the gender or age of the patient. This statement 
agrees with the ADA statement that glycemic control is affected by various factors including, among others, the duration of diabetes, existing comorbidities, and vascular complications. ${ }^{11}$ Similarly, Table 3 shows that albuminuria is not associated with gender or age. This statement is in line with the study of Habib et al. ${ }^{19}$ that concluded albuminuria from renal damage may occur at all stages of life, especially in patients with type $2 \mathrm{DM}$ with poor glycemic control. The study of Showail et al. ${ }^{4}$ showed similar results, in that the factors of age and gender do not play a role in the development of microalbuminuria.

In the present study, there is higher positive albuminuria at uncontrolled $\mathrm{HbA} 1 \mathrm{c}$ levels with $p<0.001$ (Table 4 and Figure 1) and the correlation between $\mathrm{HbA} 1 \mathrm{c}$ and albuminuria is significant, with $\mathrm{r}=0.865$ and $\mathrm{p}<0.001$ (Figure 2). It shows that a significant positive correlation between $\mathrm{HbA1c}$ and albuminuria is present, indicating that the higher the HbA1c concentration is, the more severe the albuminuria. These results are in agreement with those of the study of Muraliswaran et al. ${ }^{10}$ that demonstrated a significant correlation between HbA1c and albuminuria ( $r=0.5590$ and $\mathrm{p}=0.05$ ). Muraliswaran et al. ${ }^{10}$ obtained data from subjects without systemic disease such as cardiovascular disease, cerebrovascular disease, urinary tract infection, and type $1 \mathrm{DM}$. Other studies with similar results are the studies by Showail et al. ${ }^{4}$, Chiu et al. ${ }^{5}$, and Kundu et al. ${ }^{20}$ showing that poor glycemic control is associated with the increasing incidence of albuminuria.

In conclusion, there is a significant positive correlation between HbA1c concentration and albuminuria in patients with type $2 \mathrm{DM}$. Uncontrolled HbA1c levels may cause higher albuminuria. In patients with type $2 \mathrm{DM}$, achieving satisfactory glycemic control is a must to obtain HbA1c concentration target in order to prevent or delay the development of renal damage.

\section{Acknowledgments}

The authors express their gratitude to the staff of Dr. Soetomo Hospital, Surabaya, for permission and location of the study and support in all aspects of the study.

\section{References}

1. WHO. Global status report on noncommunicable diseases 2014. Geneva: WHO Library Cataloguing in Publication Data; 2014.

2. Ozougwu O, Obimba KC, Belonwu CD, Unakalamba CB. The pathogenesis and pathophysiology of type 1 and type 2 diabetes mellitus. J Physiol Pathophysiol. 2013;4(4):46-57.

3. Keating BJ. Advances in risk prediction of type 2 diabetes: Integrating genetic scores with framingham risk models. Diabetes. 2015;64(5):1495-7.

4. Showail AA l, Ghoraba M. The association between glycemic control and microalbuminuria in Type 2 diabetes. Saudi J Kidney Dis Transpl. 2016;27(3):473-9.

5. Chiu WC, Lai YR, Cheng BC, Huang CC, Chen JF, Lu CH. HbA1C Variability is strongly associated with development of macroalbuminuria in normal or microalbuminuria in patients with type 2 diabetes mellitus: a six-year follow-up study. Biomed Res Int. 2020;2020:7462158

6. Zhang J, Liu J, Qin X. Advances in early biomarkers of diabetic nephropathy. Rev Assoc Med Bras. 2018;64(1):85-92.

7. Carls G, Huynh J, Tuttle E, Yee J, Edelman S V. Achievement of Glycated Hemoglobin Goals in the US Remains Unchanged Through 2014. Diabetes Ther. 2017;8(4):863-73. DOI 10.1007/s13300-017-0280-5.

8. Tarigan TJE, Yunir E, Subekti I, Pramono LA, Martina D. Profile and analysis of diabetes chronic complications in outpatient diabetes clinic of Cipto Mangunkusumo Hospital, Jakarta. Med J Indones. 2015;24(3):156-62.

9. American Diabetes Association. 6. Glycemic Targets: Standards of Medical Care in Diabetes-2020. Diabetes Care. 2020;43:S6676. https://doi.org/10.2337/dc20-S006.

10. Muraliswaran P, Aparna G, Kanagavalli P, Srikanth S. Prevalence of microalbuminuria in relation to HbA1c among known type2 diabetic patients in Puducherry population. Res J Pharm Biol Chem Sci. 2013;4(1):45862.

11. American Diabetes Association. 2. Classification and Diagnosis of Diabetes: Standards of Medical Care in Diabetes-2020. Diabetes Care. 2020;43(Suppl 1):S14-31.

12. Shrivastava SRBL, Shrivastava PS, Ramasamy J. Role of self-care in management of diabetes mellitus. J Diabetes Metab Disord. 2013;12(1):14.

13. Litwak L, Goh SY, Hussein Z, Malek R, Prusty V, Khamseh ME. Prevalence of diabetes 
complications in people with type 2 diabetes mellitus and its association with baseline characteristics in the multinational A1chieve study. Diabetol Metab Syndr. 2013;5(1):57.

14. Papatheodorou K, Banach M, Bekiari E, Rizzo M, Edmonds M. Complications of diabetes 2017. J Diabetes Res. 2018;2018:3086167.

15. Modesti PA, Bamoshmoosh M, Rapi S, Massetti L, Bianchi S, Al-Hidabi D, et al. Relationship between hypertension, diabetes and proteinuria in rural and urban households in Yemen. J Hum Hypertens. 2013;27(9):572-9.

16. Becker GJ, Wheeler DC, De Zeeuw D, Fujita T, Furth SL, Holdaas H, et al. Kidney disease: Improving global outcomes (KDIGO) blood pressure work group. KDIGO clinical practice guideline for the management of blood pressure in chronic kidney disease. Kidney Int Suppl. 2012;2(5):337-414.

17. Pasko N, Toti F, Strakosha A, Thengjilli
E, Shehu A, Dedej T, et al. Prevalence of microalbuminuria and risk factor analysis in type 2 diabetes patients in Albania: The need for accurate and early diagnosis of diabetic nephropathy. Hippokratia. 2013;17(4):33741.

18. Niveditha H, Yogitha C, Liji P, Sundeep $\mathrm{S}$, Himamshu NVV, Vinutha BV, et al. Clinical correlation of $\mathrm{HbA} 1 \mathrm{C}$ and diabetic nephropathy with diabetic retinopathy. J Evol Med Dent Sci. 2013;2(49):9430-5.

19. Habib MB, Akbar NS. Association of Microalbuminuria with HbA1c in Patients of Type II diabetes mellitus in different age groups and genders. Diabetes Case Rep. 2018;3:1-4.

20. Kundu D, Roy A, Mandal T, Bandyopadhyay U, Ghosh E, Ray D. Relation of microalbuminuria to glycosylated hemoglobin and duration of type 2 diabetes. Niger J Clin Pract. 2013;16(2):216-20. 